\title{
ASURANSI KERANGKA KAPAL PERIKANAN SEBAGAI STRATEGI MANAJEMEN RISIKO (STUDI KASUS: PERUSAHAAN UMUM PERIKANAN INDONESIA)
}

\section{FISHING VESSEL FRAME INSURANCE AS A RISK MANAGEMENT STRATEGY (CASE STUDY: PERUSAHAAN UMUM PERIKANAN INDONESIA)}

\author{
Bunga Mega Aprilia ${ }^{1}$, Fis Purwangka ${ }^{1}$, Akhmad Solihin $^{1}$ \\ ${ }^{1}$ Departemen Pemanfaatan Sumberdaya Perikanan, \\ Fakultas Perikanan dan Ilmu Kelautan, Institut Pertanian Bogor \\ Korespondensi: fis@psp-ipb.org
}

\begin{abstract}
Fishing vessel operational activities have a high risk of accidents, those causing losses to the ship owner. The government has required fishing vessel frame insurance to the ship owner through a mandatory circular for the removal of the ship's framework and/or compensation protection. This study aims to describe the rules of ship insurance in Indonesia with a normative juridical law. Next, identify fishing vessel requirements for submission of insurance with a descriptive analysis and find out the gap in the implementation of fishing vessel frame insurance at Perum Perindo and provide recommendations for implementation with gap analysis. The results of this study, it is known that the rules regarding fishing vessel frame insurance contained in Law No. 17/2008 (Article 203), PP No. 5/2010 (Article 119), and PermenHub No. 71/2013 (Article 18). Required insurance requirements are grosse akta, surat ukur, and pas besar. The implementation gap for fishing vessel frame insurance at Perum Perindo is $40 \%$. Recommendations for implementing insurance are suggested that the ship owner completes the document of ownership of the ship which is the insurance requirement and the preparation of funds to pay premiums to third parties.
\end{abstract}

Keywords: fishing vessel frame, insurance, Perum Perindo

\begin{abstract}
ABSTRAK
Kegiatan operasional kapal perikanan memiliki risiko kecelakaan yang tinggi, sehingga mengakibatkan kerugian bagi pemilik kapal. Pemerintah telah mewajibkan asuransi kapal perikanan kepada pemilik kapal melalui surat edaran wajib asuransi penyingkiran kerangka kapal dan/atau perlindungan ganti rugi. Penelitian ini bertujuan untuk mendeskripsikan aturan asuransi kerangka kapal perikanan di Indonesia dengan pendekatan hukum yuridis normatif. Selanjutnya, mengidentifikasi persyaratan kapal perikanan untuk pengajuan asuransi dengan analisis deskriptif kualitatif dan mengetahui gap pelaksanaan asuransi kerangka kapal di Perum Perindo serta memberikan rekomendasi pelaksanannya dengan gap analysis. Hasil penelitian ini, diketahui bahwa aturan mengenai asuransi kerangka kapal perikanan tertuang dalam UU No. 17/2008 (Pasal 203), PP No. 5/2010 (Pasal 119), dan PermenHub No. 71/2013 (Pasal 18). Persyaratan asuransi yang dibutuhkan adalah grosse akta, surat ukur, dan pas besar. Gap pelaksanaan asuransi kerangka kapal di Perum Perindo sebesar 40\%. Rekomendasi pelaksanaan asuransi yang disarankan yaitu, pemilik kapal melengkapi dokumen kepemilikan kapal yang menjadi syarat asuransi dan penyusunan dana untuk membayar premi kepada pihak ketiga.
\end{abstract}

Kata kunci: asuransi, kerangka kapal perikanan, Perum Perindo 


\section{PENDAHULUAN}

Perikanan tangkap merupakan salah satu usaha yang memiliki karakteristik yang berbeda dengan usaha lainnya, karena usaha ini penuh dengan tantangan serta dihadapkan pada risiko dan ketidakpastian (Lindawati dan Rahadian 2016). Usaha perikanan tangkap bergantung pada modal utama dan faktor-faktor lain sebagai penentu keberhasilan pengembangan usaha. Badriyah et al. (2019) menyatakan bahwa salah satu modal utama dalam kegiatan usaha perikanan tangkap adalah kapal perikanan. Kapal perikanan mendukung kegiatan operasional penangkapan ikan yang meliputi pencarian keberadaan ikan yang menjadi target penangkapan, pengoperasian alat tangkap, dan membawa hasil tangkapan ke darat.

Kegiatan operasional kapal perikanan yang beragam, mengharuskan kapal berada dalam kondisi stabil dan laiklaut. Hal tersebut senada dengan pernyataan Budiman et al. (2016), bahwa setiap kapal yang berlayar harus berada dalam kondisi laiklaut sehingga menjamin keselamatan dan keamanan selama kapal berlayar. Kapal yang tidak dalam kondisi laiklaut memiliki risiko kecelakaan tinggi, kecelakaan tersebut dapat disebabkan oleh faktor manusia maupun faktor alam yang menyebabkan kapal terbalik, terbakar, bahkan tenggelam (Tjahjanto dan Azis 2016).

Risiko yang dapat terjadi secara tidak terduga dapat menimbulkan kerugian bagi pemilik kapal. Salah satu cara untuk menangani risikonya adalah dengan mengasuransikan kapal (Novi et al. 2016). Asuransi adalah salah satu sarana yang banyak digunakan untuk manajemen risiko untuk melindungi dan memitigasi berbagai risiko, seperti risiko aset, risiko produksi, risiko pasar, risiko pribadi, dan risiko kesehatan (Parappurathu et al. 2017). Undang-Undang (UU) No. 40/2014 tentang Perasuransian menyatakan bahwa asuransi merupakan sebuah perjanjian dengan penanggung mengikatkan diri kepada tertanggung dengan menerima premi untuk memberikan pergantian kepadanya karena kerugian, kerusakan, atau kehilangan keuntungan yang diharapkan yang mungkin dideritanya akibat dari suatu evenemen atau peristiwa tidak pasti.

Asuransi dalam usaha perikanan tangkap salah satunya adalah asuransi kerangka kapal. Menurut UU No. 17/2008 tentang Pelayaran, kerangka kapal harus diasuransikan oleh pemiliknya sebagai perlindungan ganti kerugian. Hal ini ditegaskan oleh Direktorat Jenderal Perhubungan Laut (DJPL) melalui surat edaran kepada pemilik kapal untuk melaksanakan kewajiban asuransi kerangka kapal dan/atau perlindungan ganti rugi. Apabila pemilik kapal tidak mengasuransikan kerangka kapal yang dimiliki, maka pemilik kapal dikenakan sanksi berupa peringatan, pembekuan izin, hingga pencabutan izin usaha (www.dephub.go.id).

Salah satu pemilik kapal yang menerima surat edaran wajib asuransi tersebut adalah Perusahaan Umum Perikanan Indonesia (Perum Perindo). Menurut UU No. 19/2013 tentang Badan Usaha Milik Negara (BUMN), Perum Perindo merupakan salah satu BUMN yang memiliki tugas dan tanggung jawab untuk mengelola aset negara dengan menyelenggarakan pengusahaan dan pelayanan barang jasa dan pengembangan sistem bisnis perikanan. Saat ini, pemilik kapal menginginkan mekanisme asuransi dengan baik. Oleh karena itu, penelitian ini penting untuk mengetahui gap pelaksanaan asuransi kerangka kapal perikanan di Perum Perindo dan memberikan informasi pelaksanaan asuransi kerangka kapal perikanan kepada pemilik kapal lain agar dapat mengalihkan risiko kerugian kecelakaan kapal dengan asuransi kerangka kapal. Berdasarkan permasalahan yang disebutkan, penelitian bertujuan mendeskripsikan aturan asuransi kerangka kapal perikanan dan mengidentifikasi persyaratan asuransi kerangka kapal perikanan serta mengetahui gap antara aturan dan persyaratan untuk memberikan rekomendasi pelaksanaan asuransi kerangka kapal perikanan.

\section{METODE PENELITIAN}

Penelitian ini dilakukan pada bulan Oktober 2019-April 2020 di Perusahaan Umum Perikanan Indonesia (Perum Perindo) Jalan Muara Baru, Jakarta Utara. Pemilihan Perum Perindo karena perusahaan ini memiliki risiko kerugian yang sangat tinggi, selain itu Perum Perindo dapat menjadi acuan atau referensi perusahaan perikanan yang lain untuk melaksanakan asuransi kerangka kapal perikanan.

Metode yang digunakan dalam penelitian ini yaitu metode studi kasus. 
Penelitian terhadap kasus ini difokuskan pada asuransi kerangka kapal perikanan sebagai strategi manajemen risiko. Tujuan pertama dibutuhkan data yang meliputi Peraturan Perundang-undangan (UU No. 17/2008), Peraturan Pemerintah (PP No. 5/2010 tentang Kenavigasian), dan Peraturan Menteri Perhubungan (PermenHub No. 71/2013 tentang Salvage dan/atau Pekerjaan Bawah Air). Tujuan kedua dibutuhkan data dokumen kepemilikan kapal (grosse akta, surat ukur, dan pas besar) yang menjadi persyaratan untuk pengajuan asuransi. Tujuan ketiga data yang diperoleh dari tujuan pertama dan kedua yaitu peraturan dan persyaratan dalam pelaksanaan asuransi kerangka kapal. Data-data tersebut diperoleh melalui studi pustaka dan wawancara.

Penentuan narasumber dalam penelitian ini ditentukan dengan menggunakan teknik purposive sampling, yaitu dengan mempertimbangkan bahwa narasumber dianggap paling tahu tentang informasi yang dibutuhkan oleh peneliti sehingga akan memudahkan peneliti menjelajahi objek atau situasi yang diteliti (Sugiyono 2010). Narasumber dalam penelitian ini berjumlah sebanyak dua orang dari divisi pengelolaan hasil perikanan yang bertugas dalam pembuatan rencana pengoperasian armada, yaitu satu orang administrasi/pengurus izin dokumen kapal dan satu orang pengadaan kebutuhan kapal. Analisis yang digunakan dalam penelitian ini terdiri atas tiga macam, yaitu analisis yuridis normatif, analisis deskriptif, dan gap analysis. Analisis yuridis normatif adalah pendekatan pada ilmu hukum yang menitikberatkan pada norma dan kaidah hukum dalam memecahkan permasalahan (Zaini 2011). Kegiatan analisis ini adalah mengumpulkan bahan primer dan sekunder, yaitu Peraturan Perundang-undangan, yang mengatur kewajiban asuransi kerangka kapal perikanan. Melalui proses penelitian tersebut maka diadakan analisa terhadap data yang dikumpulkan dan diolah (Muchtar 2015).

Analisis deskriptif digunakan untuk mengidentifikasi permasalahan dan menjelaskan informasi mengenai persyaratan kerangka kapal perikanan yang dapat diasuransikan. Informasi yang didapatkan akan diolah dan disajikan dalam bentuk deskripsi yang mencakup dokumen kepemilikan kapal perikanan untuk pengajuan asuransi, prosedur pengajuan asuransi, data kapal Perum Perindo, dan kriteria kerangka kapal kayu yang dapat diasuransikan menurut BKI.

Menurut Muchsam et al. (2011) gap analysis atau analisis kesenjangan merupakan suatu pendekatan yang digunakan untuk mengetahui tingkat kinerja suatu perusahaan atau institusi. Gap analysis juga dipakai untuk mengetahui kinerja dari sistem yang sedang berjalan dengan sistem standar. Dalam kondisi umum, kinerja suatu perusahaan atau institusi dapat tercermin dalam sistem operasional maupun strategi yang digunakan oleh institusi tersebut.

Perhitungan gap analysis sebagaimana disajikan pada Tabel 1 dihitung dengan cara menjumlahkan setiap ketentuan yang sudah diimplementasikan pada kapal, kemudian dibagi dengan jumlah dari setiap ketentuan. Jika ketentuan sudah diimplementasikan akan mendapat nilai 1 dan jika belum akan mendapat nilai 0 . Perhitungan dilakukan pada seluruh ketentuan dalam peraturan UU No.17/2008 (Pasal 203), PP No.51/2010 (Pasal 119), PermenHub No.71/2013 (Pasal 18), Persyaratan dokumen kepemilikan kapal (grosse akta, surat ukur, dan pas besar).

Tabel 1. Perhitungan gap pelaksanaan asuransi kerangka kapal perikanan

\begin{tabular}{|c|c|c|c|}
\hline \multirow{2}{*}{ Ketentuan } & \multicolumn{2}{|c|}{ Implementasi } & \multirow{2}{*}{ Keterangan } \\
\hline & $\mathbf{Y a}$ & Tidak & \\
\hline A & 1 & 0 & \\
\hline B & 1 & 0 & \\
\hline C.dst & 1 & 0 & \\
\hline Gap & plem & entuan & \\
\hline
\end{tabular}




\section{HASIL DAN PEMBAHASAN}

\section{Hasil}

\section{Kondisi umum Perum Perindo}

Pengusahaan dan pelayanan Perum Perindo dilaksanakan di enam pelabuhan perikanan, yaitu: Pelabuhan Perikanan Samudera (PPS) Nizam Zachman Jakarta, PPS Belawan, Pelabuhan Perikanan Nusantara (PPN) Pekalongan, PPN Brondong, PPN Pemangkat, dan PPN Prigi. Perum Perindo memiliki peranan dan posisi yang sangat strategis dalam upaya mendukung visi dan misi Pemerintah, khususnya Kementerian BUMN untuk meningkatkan kualitas pengelolaan perusahaan yang transparan dan akuntabel, mendorong pertumbuhan ekonomi regional dan nasional serta pendapatan negara dan pembangunan nasional melalui pembangunan dan pengembangan sektor kelautan dan perikanan (Maulida 2014).

Perum perindo memiliki tiga fokus lini usaha yaitu: pra-produksi dengan subsistemnya bernama fishery estate, produksi dengan sub-sistem didalamnya adalah aqua culture \& fleet operation, dan pengolahan \& pemasaran dengan subsistem didalamnya adalah trade \& processing. Lini usaha pada fishery estate diantaranya tambat labuh, pemanfaatan lahan industri (sewa), docking, pabrik es, cold storage, BBM, air bersih, telepon, listrik, dan jaringan data. Aqua culture memiliki lini usaha diantaranya tambak udang, tambak bandeng, keramba jaring apung (KJA), dan pabrik pakan. Fleet operation memiliki lini usaha diantaranya penangkapan ikan dan pengangkutan ikan. Sedangkan trade \& processing memiliki lini usaha diantaranya perdagangan ikan $\&$ hasil laut, pengolahan ikan \& hasil laut, dan ekspor \& impor. Terdapat 29 lokasi, yaitu lima cabang dan 24 unit kerja telah beroperasi serta empat unit dalam proses pengembangan terdapat di daerah Cilacap, Gorontalo, Kolaka, dan Kupang.

$$
\text { Perum Perindo menyadari }
$$
pentingnya menjaga aset yang diberikan oleh negara, salah satunya yaitu mengasuransikan kapal perikanan yang digunakan dalam operasional penangkapan dan pengangkutan ikan, sehingga Perum Perindo mengalihkan pergantian risiko kepada perusahaan asuransi sebagai pihak penanggung. Perum Perindo memiliki lima kapal yang digunakan pada tahun 20192020. Menyadari tingginya risiko yang ditanggung Perum Perindo, maka tiga kapal perikanan sudah diasuransikan, sementara dua kapal lainnya belum diasuransikan karena tidak memenuhi persyaratan asuransi kapal perikanan.

\section{Asuransi kerangka kapal perikanan}

Asuransi disebut juga sebagai pertanggungan, karena terdapat dua pihak yang terlibat didalamnya yaitu pihak penanggung dan pihak tertanggung. Pihak penanggung berarti pihak yang sanggup menanggung atau menjamin bahwa pihak tertanggung akan mendapatkan penggantian suatu kerugian yang mungkin akan ia derita sebagai akibat dari peristiwa yang semula belum tentu akan terjadi atau semula dapat ditentukan saat akan terjadi. Sementara itu, pihak tertanggung diwajibkan untuk membayar premi kepada pihak penanggung (Njatrijani 2018). Premi asuransi merupakan sejumlah uang yang wajib dibayar oleh pihak tertanggung kepada pihak penanggung dalam jangka waktu tertentu, biasanya setiap bulan atau setiap tahun selama asuransi berlangsung. Besarnya jumlah premi tergantung pada jumlah tanggungan asuransi yang disetujui oleh pihak tertanggung saat diadakan asuransi yang tertulis dalam polis (Nasir 2016). Menurut Nugroho (2011) polis asuransi merupakan dasar perikatan dalam asuransi yang dilakukan oleh pihak tertanggung dan pihak penanggung, polis digunakan sebagai alat bukti halhal yang disepakati untuk pergantian kerugian dalam bentuk akta. Kitab UndangUndang Hukum Dagang (KUHD) Pasal 246 menyatakan, bahwa di dalam polis asuransi harus memuat hal-hal sebagai berikut: (a) waktu tidak berlakunya asuransi; (b) pihak yang bertanggung jawab untuk menutup asuransi atas tanggungan; (c) suatu uraian yang cukup jelas mengenai barang yang diasuransikan; (d) jumlah uang untuk pergantian kerugian; (e) bahaya-bahaya yang ditanggung oleh pihak asuransi; (f) waktu mulai berlakunya asuransi; dan (g) jumlah premi pertanggungan.

Asuransi kerangka kapal perikanan merupakan sebuah perjanjian antara pemilik kapal sebagai pihak tertanggung dengan perusahaan asuransi sebagai pihak penanggung dengan cara pihak tertanggung membayar premi kepada pihak penanggung. Pihak penanggung mempunyai kewajiban untuk memberikan pergantian kepada pemilik kapal apabila kapal tersebut 
mengalami kecelakaan, kerusakan, atau kerugian yang mungkin diderita akibat dari peristiwayang tidak pasti. Asuransi kerangka kapal perikanan juga memiliki beberapa fungsi yaitu: memberikan kekuatan hukum atas kepemilikan hak atas kerangka kapal perikanan melalui buku kapal perikanan, memfasilitasi aset kapal kayu agar dapat digunakan sebagai agunan melalui program asuransi kerangka kapal, dan memberikan jaminan penggantian kerugian terhadap risiko kecelakaan kerangka kapal perikanan (total loss) (Rani 2016).

\section{Prosedur pengajuan asuransi}

Prosedur pengajuan asuransi kerangka kapal perikanan merupakan hal-hal yang harus diperhatikan untuk pengajuan asuransi oleh pemilik kapal. Menurut Mardiyah (2013) prosedur merupakan urutan yang tepat dari tahapantahapan yang menerangkan apa yang harus dikerjakan, siapa yang harus mengerjakan, kapan mengerjakan, dan bagaimana cara mengerjakannya, hal tersebut dilakukan untuk mencapai tujuan tertentu. Prosedur pengajuan asuransi dapat dilihat pada Gambar 1.

Proses pengajuan asuransi kerangka kapal perikanan dapat dilakukan dengan cara berikut: (a) pemilik kapal mengajukan asuransi dengan cara mengirimkan dokumen secara langsung mendatangi kantor pusat atau kantor cabang terdekat perusahaan asuransi; (b) perusahaan asuransi menerima dan memeriksa formulir dan dokumen persyaratan asuransi; (c) pemilik kapal menerima pemberitahuan dari perusahaan asuransi bahwa formulir dan dokumen persyaratan untuk asuransi, telah diterima; (d) pembuatan polis asuransi oleh kedua belah pihak sesuai dengan kesepakatan; (e) jika polis asuransi telah disepakati, pemilik kapal membayarkan premi kepada pihak asuransi sesuai dengan jumlah dan waktu yang telah ditentukan; dan (f) pembayaran premi dari pemilik kapal diterima oleh perusahaan asuransi.

\section{Aturan asuransi kerangka kapal perikanan}

Kewajiban mengasuransikan kapal dengan asuransi penyingkiran kerangka kapal dan/atau perlindungan ganti rugi sesuai dengan peraturan perundangundangan yang disajikan pada Tabel 2 . Sementara itu, aturan hukum asuransi kapal disajikan pada Tabel 3.
Berdasarkan Pasal 203 ayat (1) UU No.17/2008 menyebutkan bahwa pemerintah meminta kepada pemilik kapal untuk menyingkirkan kerangka kapal dan muatannya maksimal 180 hari sejak kapal tenggelam untuk menjamin tanggung jawab pemilik kapal menyingkirkan kerangka kapal, maka pemilik wajib mengasuransikan kapalnya. Apabila penyingkiran kerangka kapal tersebut tidak dilakukan, maka pemerintah yang mengangkat, menyingkirkan, bahkan menghancurkan seluruh bagian kerangka kapal atas biaya pemilik (Pasal 203 ayat 2). Selanjutnya, pada ayat (3) menambahkan bahwa pemilik kapal wajib memberikan ganti rugi apabila kapalnya menyebabkan kecelakaan bagi kapal lain. Sementara itu, pemerintah dapat menguasai kerangka kapal tersebut apabila tidak diketahui pemiliknya dalam batas waktu yang telah ditentukan (Pasal 203 ayat 4). Pada ayat (5) menambahkan bahwa pemilik kapal diwajibkan untuk mengasuransikan kapalnya.

Berdasarkan Pasal 119 ayat (1) PP No. 5/2010 disebutkan bahwa pemilik kapal wajib memberikan asuransi kepada kapalnya. Selanjutnya, pada ayat (2) menambahkan bahwa asuransi kapal tersebut termasuk kewajiban untuk mengangkut kerangka kapal. Pada ayat (3) menambahkan bahwa kapal yang diasuransikan tidak termasuk kapal perang, kapal negara yang digunakan untuk tugas pemerintahan, kapal layar dan kapal layar bermotor, serta kapal motor dengan ukuran kurang dari 35 GT.

Berdasarkan Pasal 18 ayat (1) PermenHub No. 71/2013 disebutkan bahwa asuransi bagi pemilik kapal termasuk asuransi untuk menyingkirkan kerangka kapal dan asuransi sebagai perlindungan ganti rugi. Selanjutnya, pada ayat (2) menambahkan bahwa asuransi dilakukan oleh perusahaan atau lembaga keuangan yang diakui oleh negara. Pada ayat (3) menambahkan bahwa asuransi dibuktikan dengan polis asuransi. Ayat (4) menambahkan bahwa polis asuransi berfungsi sebagai perjanjian asuransi yang dapat dilampirkan sebagai persyaratan kelaikan kapal yang mendapatkan asuransi. Selanjutnya, pada ayat (5) menambahkan bahwa kewajiban asuransi dikecualikan bagi kapal perang, kapal negara yang digunakan untuk melakukan tugas pemerintahan, dan kapal motor dengan ukuran kurang dari 35 GT. 


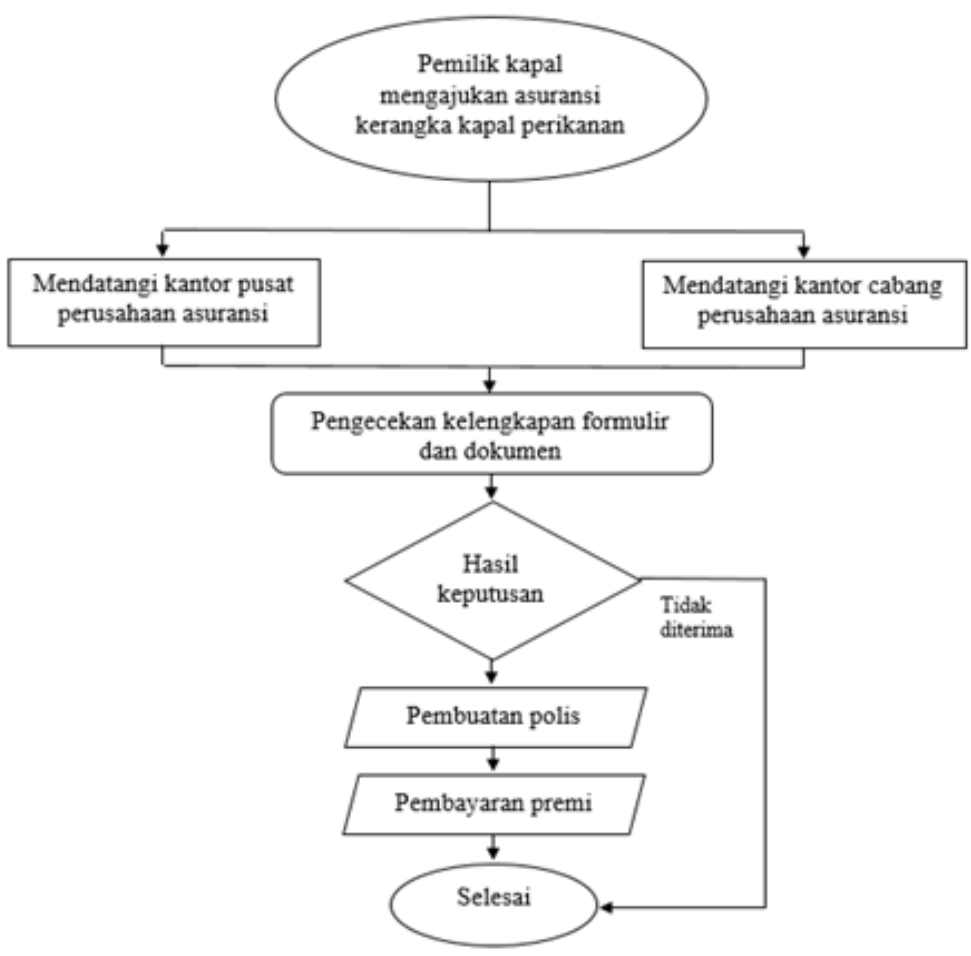

Gambar 1. Diagram alir prosedur pengajuan asuransi kerangka kapal perikanan

Tabel 2. Dasar hukum asuransi kerangka kapal perikanan

\section{Dasar Hukum}

UU No.17/2008 (Pasal 203) Pemilik kapal wajib menyingkirkan kerangka kapal yang mengalami kecelakaan di laut. Untuk menjamin kewajiban tersebut maka, pemilik kapal wajib mengasuransikan kapalnya

PP No. 5/2010 (Pasal 119)

PermenHub No. $71 / 2013$ (Pasal 18)
Kewajiban asuransi kapal, dikecualikan bagi kapal perang, kapal negara yang digunakan untuk tugas pemerintahan, kapal layar, dan kapal motor dengan ukuran kurang dari 35 GT (gross tonnage)

Kewajiban asuransi kapal dibuktikan dengan polis atau perjanjian asuransi
Asuransi kerangka kapal yang dimaksud adalah untuk semua jenis kapal yang berlayar di perairan Indonesia termasuk kapal perikanan. Apabila pemilik kapal tidak mengikuti aturan kewajiban mengenai asuransi kerangka kapal, maka akan dikenakan sanksi. Sanksi atau hukuman yang dikenakan dapat berupa hukuman perdata dan hukuman pidana.

1. Hukum Perdata

Hukum perdata berlaku apabila kapal yang berlayar mengalami kecelakaan di laut, pencemaran air laut, dan rusaknya ekosistem yang mengakibatkan terganggunya jalur pelayaran sehingga merugikan pihak lain. Hukuman ini dikenakan langsung kepada pemilik kapal dengan membayar denda dan penjara sesuai ketentuan yang berlaku. Menurut Ginting (2013) hukum perdata dimaksudkan untuk memberikan rasa aman terhadap individu, kelompok, organisasi atau lembaga dalam melaksanakan aktifitas kesehariannya. Rasa aman yang dimaksud adalah perasaan tenang tanpa adanya kekhawatiran akan ancaman ataupun perbuatan yang merugikan, baik antar individu maupun masyarakat.

2. Hukum Pidana

Hukum pidana berlaku apabila pemilik kapal tidak melakukan kewajiban untuk mengasuransi kapal yang dimiliki dengan asuransi penyingkiran kerangka kapal dan perlindungan ganti rugi. Menurut Ilyas (2012) hukum pidana adalah ketentuan yang mengatur tentang apa yang tidak boleh dilakukan beserta sanksinya. Suatu peristiwa dikatakan sebagai tindak pidana 
dan dapat dipertanggungjawabkan kepada pelakunya apabila perbuatan tersebut telah dirumuskan dalam suatu perudangan yang berlaku. Atau dengan kata lain, tindak pidana merupakan suatu perbuatan yang dilakukan dalam keadaan dan situasi yang tertentu oleh undang-undang dinyatakan terlarang, yang karenanya mengakibatkan hukuman badan atau denda kepada pelakunya (Utomo et al. 2017).

Tabel 3. Butir hukum asuransi kerangka kapal perikanan

Dasar Hukum Keterangan

UU No.17/2008 (1) Pemilik kapal wajib menyingkirkan kerangka kapal dan/atau mua-

(Pasal 203) tannya yang mengganggu keselamatan dan keamanan pelayaran paling lama 180 hari kalender sejak kapal tenggelam.

(2) Pemerintah wajib mengangkat, menyingkirkan/menghancurkan seluruh/atau sebagian dari kerangka kapal dan/atau muatannya atas biaya pemilik apabila dalam batas waktu yang ditetapkan pemerintah, pemilik tidak melaksanakan tanggung jawab dan kewajibannya sebagaimana dimaksud pada ayat (1).

(3) Pemilik kapal yang lalai melaksanakan kewajiban dalam batas waktu yang ditetapkan pemerintah sebagaimana dimaksud pada ayat (1) sehingga mengakibatkan terjadinya kecelakaan pelayaran, wajib membayar ganti kerugian kepada pihak yang mengalami kecelakaan.

(4) Pemerintah wajib mengangkat dan menguasai kerangka kapal dan/ atau muatannya yang tidak diketahui pemiliknya dalam batas waktu yang telah ditentukan.

(5) Untuk menjamin kewajiban sebagaimana dimaksud pada ayat (1) dan ayat (2) pemilik kapal wajib mengasuransikan kapalnya.

(6) Ketentuan lebih lanjut mengenai tata cara dan persyaratan pengangkatan kerangka kapal dan/atau muatannya diatur dengan Peraturan Menteri.

PP No. 5/2010 (1) Pemilik kapal wajib mengasuransikan kapalnya.

(Pasal 119) (2) Asuransi kapal sebagaimana dimaksud pada ayat (1) termasuk asuransi atas kewajiban mengangkat kerangka kapal.

(3) Kewajiban mengasuransikan sebagaimana dimaksud pada ayat (1) dikecualikan bagi: (a) kapal perang; (b) kapal negara yang digunakan untuk melakukan tugas pemerintahan; (c) kapal layar dan kapal layar motor; atau (d) kapal motor dengan tonase kotor kurang dari GT 35 GT.

PermenHub No. $71 / 2013$ (Pasal 18)

(1) Pemilik kapal wajib mengasuransikan kapalnya dengan asuransi atas kewajiban menyingkirkan kerangka kapal (wreck removal insurance) dan/ atau asuransi perlindungan dan ganti rugi (protection and indemnity).

(2) Asuransi sebagaimana dimaksud pada ayat (1) dilakukan oleh perusahaan asuransi atau lembaga keuangan penjamin yang diakui oleh Pemerintah.

(3) Kewajiban mengasuransikan penyingkiran kerangka kapal sebagaimana dimaksud pada ayat (1) dibuktikan dengan pemilikan polis asuransi atau sertifikat dana jaminan penyingkiran kerangka kapal.

(4) Polis asuransi atau sertifikat dana jaminan penyingkiran kerangka kapal sebagaimana dimaksud pada ayat (3) wajib dilampirkan sebagai persyaratan kelaikan kapal dan pengoperasian kapal di pelabuhan.

(5) Kewajiban mengasuransikan sebagaimana dimaksud pada ayat (1) dikecualikan bagi: a. kapal perang; b. kapal negara yang digunakan untuk melakukan tugas pemerintahan; dan c. kapal motor dengan tonase kotor kurang dari GT 35 GT. 


\section{Persyaratan perikanan}

Dokumen kepemilikan kapal perikanan yang menjadi syarat asuransi

Pemilik kapal perikanan memiliki beberapa dokumen sebagai bukti kepemilikan kapal untuk mendirikan usaha di bidang perikanan dan menjadi persyaratan untuk asuransi kerangka kapal di antaranya adalah grosse akta, surat ukur, dan pas besar. Perum Perindo memiliki lima kapal perikanan, tiga sudah mendapatkan jaminan asuransi dan dua belum mendapatkan jaminan asuransi. Hal ini dikarenakan dua kapal yang belum mendapatkan asuransi tidak memenuhi persyaratan yang dibutuhkan. Adapun rinciannya dapat dilihat pada Tabel 4.

Berdasarkan Tabel 4 terlihat bahwa KM Perindo Jaya, KM Gemilang Samudera, dan KM Setia Utama sudah memiliki dokumen yang lengkap untuk memenuhi persyaratan asuransi kerangka kapal perikanan. Kondisi sebaliknya, bahwa KM Dewi Putri dan KM Berkat belum memiliki dokumen yang lengkap untuk memenuhi persyaratan asuransi kapal perikanan. Hal ini dikarenakan KM Dewi Putri dan KM Berkat belum memiliki surat ukur dan pas besar untuk pemenuhan persyaratan asuransi.

\section{Grosse akta}

Grosse akta kapal perikanan merupakan sebuah bukti tanda pendaftaran kapal perikanan. PP No. 51/2002 tentang Perkapalan, Akta pendaftaran kapal yang dikeluarkan oleh Dirjenperla yang memuat pendaftaran hak milik atas kapal, pengalihan hak milik atas kapal yang telah didaftar, dan hak kebendaan lainnya atas kapal. Akta tersebut harus memuat halhal diantaranya adalah nomor dan tanggal akta, nama dan tempat kedudukan pejabat pendaftaran kapal, nama dan domisili pemilik, data kapal, dan uraian singkat kepemilikan kapal. Grosse akta ini berlaku selamanya apabila tidak ada perubahan. Ada beberapa hal yang harus dilengkapi dalam pembuatan grosse akta, diantaranya adalah: (a) surat permohonan; (b) surat ukur; (c) bukti kepemilikan hak milik, dapat berupa: akta jual beli dihadapan notaris, akta hibah dibuat dihadapan notaris, penetapan waris, penetaptan pengadilan yang mempunyai kekuatan hukum tetap, atau risalah lelang; (d) identitas pemilik: Kartu Tanda Penduduk (KTP) untuk perseorangan, akta pendirian perusahaan dan pengesahan dari Kementerian Hukum dan HAM, dan surat kuasa jika dikuasakan beserta fotocopy KTP pemberi kuasa.

\section{Surat ukur}

Berdasarkan PermenHub No. 8/2013, surat ukur adalah surat kapal yang memuat ukuran dan tonase kapal berdasarkan hasil pengukuran. Pasal 8 ayat (1) menyatakan, bahwa surat ukur diterbitkan untuk kapal dengan ukuran tonase kotor (GT) sekurang-kurangnya 7. Surat Ukur dibedakan dalam tiga jenis, yaitu surat ukur dalam negeri, surat ukur internasional, dan surat ukur khusus. Pasal 9 ayat (1) surat ukur berlaku selama kapal tidak mengalami perubahan ukuran, tonase, nama kapal, atau kapal tidak dipergunakan lagi. Surat ukur menjadi tidak berlaku dan harus diterbitkan surat ukur baru apabila kapal mengalami perubahan bangunan yang menyebabkan rincian ukuran dan/atau tonase kapal yang tercantum dalam surat ukur berubah atau kapal ganti nama. Surat ukur juga menjadi tidak berlaku, apabila kapal tidak dipergunakan lagi karena ditutuh (scraping), tenggelam, musnah, terbakar, dan dinyatakan hilang. Surat ukur dinyatakan batal apabila pengukuran dilakukan tidak sesuai dengan ketentuan dan diperoleh secara tidak sah.

Tabel 4. Daftar kapal milik Perum Perindo 2019/2020

\begin{tabular}{lccccc}
\hline \multicolumn{1}{c}{ Nama Kapal } & GT & Jenis Kapal & Grosse Akta & Surat Ukur & Pas Besar \\
\hline KM Perindo Jaya & 192 GT & Pengangkut & $\sqrt{ }$ & $\sqrt{ }$ & $\sqrt{ }$ \\
KM Setia Utama & 132 GT & Pengangkut & $\sqrt{ }$ & $\sqrt{ }$ & $\sqrt{ }$ \\
KM Gemilang Samudera & 140 GT & Penangkap & $\sqrt{ }$ & $\sqrt{ }$ & - \\
KM Dewi Putri & 127 GT & Penangkap & $\sqrt{ }$ & - & - \\
KM Berkat & 116 GT & Penangkap & $\sqrt{ }$ & - & \\
\hline
\end{tabular}


Pas besar

Pas Besar merupakan dokumen kepemilikan kapal sebagai surat tanda kebangsaan kapal yang sah. Dokumen ini dapat dijadikan sebagai pengajuan asuransi dalam perjalanan pelayaran dan sebagai jaminan kredit usaha. Pasal 59 PermenHub No. 39/2017 menyebutkan, bahwa pas besar dapat diperoleh dengan cara pemilik kapal mengajukan permohonan kepada syahbandar di pelabuhan kapal terdaftar melalui Sistem Pendaftaran Kapal Elektronik (SPKE). Permohonan tersebut wajib dilengkapi dengan: (a) fotokopi grosse akta pendaftaran kapal atau grosse akta baliknama kapal; (b) fotokopi surat ukur; dan (c) surat keterangan dari pemilik kapal mengenai data dan penggunaan kapal.

Syahbandar melakukan pengecekan kelengkapan persyaratan paling lama dua hari kerja sejak permohonan diterima. Apabila persyaratan belum terpenuhi, maka syahbandar menolak permohonan melalui SPKE atau surat secara tertulis kepada pemilik kapal untuk melengkapi persyaratan paling lama dua hari kerja. Permohonan yang ditolak tersebut, dapat diajukan kembali apabila kekurangan persyaratan telah dilengkapi. Kelengkapan persyaratan yang telah terpenuhi tersebut akan diberikan kepada syahbandar sehingga syahbandar dapat menerbitkan Pas Besar, kemudian dicatat dalam buku register. Pas Besar tersebut diberi nomor urut, nomor halaman, dan nomor buku register kemudian dilaporkan kepada DJPL.

Kapal kayu untuk pengajuan asuransi menurut BKI (Biro Klasifikasi Indonesia)

Biro Klasifikasi Indonesia (BKI) memiliki kegiatan inti yaitu melakukan klasifikasi kapal dan kelengkapannya sesuai aturan dan prosedur yang dikembangkan oleh BKI sebagai klasifikasi nasional yang berdaulat. Klasifikasi bertujuan untuk memberikan kepastian tentang kondisi kapal kepada para pemangku kepentingan, mulai dari pemilik kapal, perusahaan pelayan hingga lembaga asuransi dan perbankan. Terkait dengan klasifikasi, BKI juga melakukan kegiatan usaha statutoria, yaitu memeriksa kesesuaian kapal dan badan apung lainnya dengan ketentuan tertentu. Umumnya berupa konvensi yang diterbitkan oleh International Maritime Organization (IMO) dan ketentuan yang dikembangkan oleh pemerintahan negara anggota IMO (BKI 2014). BKI juga membuat aturan konstruksi untuk kapal kayu. Pembangunan konstrusksi kapal kayu melalui proses perencanaan kapal sesuai dengan prosedur yang benar. Adanya perhitungan konstruksi dalam perencanaan kapal adalah hal yang utama, selain kapal tersebut masuk kedalam kelas BKI, kapal tersebut juga bisa mendapatkan asuransi karena kekuatan dari konstruksi tersebut akan lebih terjamin ketimbang dari perhitungan-perhitungan yang hanya berdasarkan pengalaman bukan hasil riset (Budiarto dan Jokosisworo 2012).

Ketentuan konstruksi kapal kayu menurut BKI (1996):

1. Ukuran dari bagian konstruksi kayu

- Lunas, linggi haluan, linggi buritan, wrang, gading-gading, balok buritan, tutup isi geladak, kayu dengan berat jenis minimum $700 \mathrm{~kg} / \mathrm{m}^{3}$. Pada bagian gading-gading yang berlapis (laminat), lapis tengah boleh dibuat dari kayu yang lebih ringan (minimum $450 \mathrm{~kg} / \mathrm{m}^{3}$ ), dengan ketentuan tebal seluruhnya dari lapisan tengah tidak boleh melebihi 30\% dari tebal gadinggading.

- Kulit luar, balok geladak, galar balok, lutut balok, penumpu geladak, dudukan mesin, kayu mati, dan lainlain, terbuat dari kayu dengan berat jenis minimum $560 \mathrm{~kg} / \mathrm{m}^{3}$.

- Geladak dan galar bilga, terbuat dari kayu dengan berat jenis minimum $450 \mathrm{~kg} / \mathrm{m}^{3}$.

2. Berat jenis kayu tersebut untuk kayu dengan kelembaban sebesar 15\%. Bila dipergunakan kayu yang lebih ringan, maka konstruksi masing-masing diperbesar (untuk papan tebalnya, untuk gading-gading balok geladak dan penegar sekat modulus penampangnya, untuk lunas luas penampangnya) sesuai dengan perbandingan berat jenis minimum kayu menurut aturan, terhadap berat jenis kayu sebenarnya.

3. Bagian konstruksi yang penting harus dipergunakan kayu dengan mutu minimum kuat dan awet.

4. Kayu yang dipergunakan untuk bagian konstruksi harus baik, sehat, tidak ada celah dan tidak ada cacat-cacat yang dapat membahayakan dan harus mempunyai sifat mudah dikejakan. Kayu-kayu yang diawetkan dapat dipergunakan atas persetujuan BKI. Kayu yang tidak tahan terhadap air, cuaca, jamur, dan serangga tidak boleh 
dipergunakan. Kayu yang kurang tahan terhadap perubahan kering-basah yang permanen hanya boleh digunakan untuk bagian-bagian dibawah air, seperti papan alas.

5. Bagian-bagian konstruksi diatas garis air, seperti papan samping (dari kulit), geladak, bangunan atas, ambang palka, dan juga bagian konstruksi di dalam badan kapal harus dibuat dari kayu yang telah kering udara. Untuk bagianbagian konstruksi bawah garis air boleh digunakan kayu yang tidak begitu kering. Geladak ruang ikan harus dibuat dari kayu yang agak besar kelembabannya.

\section{Gap dan rekomendasi pelaksanaan asuransi kerangka kapal perikanan}

Berdasarkan hasil penelitian, tiga kapal milik Perum Perindo telah memenuhi peraturan dan persyaratan asuransi kerangka kapal. Sementara itu, dua kapal lainnya belum memenuhi ketentuan asuransi, sehingga tidak dapat diasuransikan. Hal ini dapat dijelaskan dalam Tabel 5.

Rekomendasi pelaksanaan asuransi kerangka kapal yang harus dilakukan oleh pemilik kapal adalah pemenuhan persyaratan asuransi, seperti grosse akta, surat ukur, dan pas besar pada masingmasing kapal sebagai bukti kepemilikan kapal. Selanjutnya, pemilik kapal menyusun dana untuk pembayaran premi pada tiap kapal untuk mengalihkan risiko kerugian kepada pihak ketiga dan menjalankan kewajiban sesuai dengan peraturan yang berlaku agar terhindar dari sanksi yang diberikan oleh Direktorat Jenderal Perhubungan Laut.

Tabel 5. Gap pelaksanaan asuransi kerangka kapal perikanan milik Perum Perindo

\begin{tabular}{|c|c|c|c|c|}
\hline & \multirow{2}{*}{ Ketentuan } & \multicolumn{2}{|c|}{ Implementasi } & \multirow{2}{*}{ Keterangan } \\
\hline & & Ya & Tidak & \\
\hline \multicolumn{5}{|c|}{ UU No.17/2008 (Pasal 203): } \\
\hline (1) & $\begin{array}{l}\text { Pemilik kapal wajib menyingkirkan } \\
\text { kerangka kapal dan/atau muatannya } \\
\text { yang mengganggu keselamatan dan ke- } \\
\text { amanan pelayaran paling lama } 180 \text { hari } \\
\text { kalender sejak kapal tenggelam }\end{array}$ & 3 & 2 & \multirow{6}{*}{$\begin{array}{l}\text { Terdapat } 3 \text { kapal milik } \\
\text { Perum Perindo yang su- } \\
\text { dah mengimplemantasi- } \\
\text { kan ketentuan tersebut, } \\
\text { yaitu KM Perindo Jaya, } \\
\text { KM Setia Utama, dan } \\
\text { KM Gemilang Samudera. } \\
\text { Sementara } 2 \text { kapal lain- } \\
\text { nya, yaitu KM Dewi Pu- } \\
\text { tri dan KM Berkat belum } \\
\text { mengimplementasikan } \\
\text { ketentuan tersebut. }\end{array}$} \\
\hline (2) & $\begin{array}{l}\text { Pemerintah wajib mengangkat, meny- } \\
\text { ingkirkan/ menghancurkan seluruh/ } \\
\text { atau sebagian dari kerangka kapal dan/ } \\
\text { atau muatannya atas biaya pemilik apa- } \\
\text { bila dalam batas waktu yang ditetapkan } \\
\text { pemerintah, pemilik tidak melaksanakan } \\
\text { tanggung jawab dan kewajibannya. }\end{array}$ & 3 & 2 & \\
\hline (3) & $\begin{array}{l}\text { Pemilik kapal yang lalai melaksanakan ke- } \\
\text { wajiban dalam batas waktu yang ditetap- } \\
\text { kan pemerintah sehingga mengakibatkan } \\
\text { terjadinya kecelakaan pelayaran, wajib } \\
\text { membayar ganti kerugian kepada pihak } \\
\text { yang mengalami kecelakaan. }\end{array}$ & 3 & 2 & \\
\hline (4) & $\begin{array}{l}\text { Pemerintah wajib mengangkat dan men- } \\
\text { guasai kerangka kapal dan/ atau mua- } \\
\text { tannya yang tidak diketahui pemiliknya } \\
\text { dalam batas waktu yang telah ditentukan }\end{array}$ & 3 & 2 & \\
\hline (5) & $\begin{array}{l}\text { Untuk menjamin kewajiban, pemilik kapal } \\
\text { wajib mengasuransikan kapalnya. }\end{array}$ & 3 & 2 & \\
\hline (6) & $\begin{array}{l}\text { Ketentuan lebih lanjut mengenai tata cara } \\
\text { dan persyaratan pengangkatan kerangka } \\
\text { kapal dan/ atau muatannya diatur den- } \\
\text { gan Peraturan Menteri. }\end{array}$ & 3 & 2 & \\
\hline
\end{tabular}




\section{Ketentuan}

PP No. 5/2010 (Pasal 119):

(1) Pemilik kapal wajib mengasuransikan kapalnya.

(2) Asuransi kapal termasuk asuransi atas kewajiban mengangkat kerangka kapal

(3) Kewajiban mengasuransikan dikecualikan bagi: (a) kapal perang; (b) kapal negara yang digunakan untuk melakukan tugas pemerintahan; (c) kapal layar dan kapal layar motor; atau (d) kapal motor dengan tonase kotor kurang dari GT 35 GT

PermenHub No. 71/2013 (Pasal 18):

(1) Pemilik kapal wajib mengasuransikan kapalnya dengan asuransi atas kewajiban menyingkirkan kerangka kapal (wreck removal insurance) dan/ atau asuransi perlindungan dan ganti rugi (protection and indemnity).

(2) Asuransi dilakukan oleh perusahaan asuransi atau lembaga keuangan penjamin yang diakui oleh Pemerintah.

(3) Kewajiban mengasuransikan penyingkiran kerangka kapal dibuktikan dengan pemilikan polis asuransi atau sertifikat dana jaminan penyingkiran kerangka kapal.

(4) Polis asuransi atau sertifikat dana jaminan penyingkiran kerangka kapal wajib dilampirkan sebagai persyaratan kelaikan kapal dan pengoperasian kapal di pelabuhan.

(5) Kewajiban mengasuransikan dikecualikan bagi: (a) kapal perang; (b) kapal negara yang digunakan untuk melakukan tugas pemerintahan; dan (c) kapal motor dengan tonase kotor kurang dari GT 35 GT.

Persyaratan dokumen kepemilikan kapal dalam asuransi kerangka kapal perikanan:

- Grosse akta

- Surat ukur

- Pas besar

\section{Implementasi

Ya Tidak

3

3

3

3

Perum Perindo yang sudah mengimplemantasikan ketentuan tersebut, yaitu KM Perindo Jaya, KM Setia Utama, dan KM Gemilang Samudera. Sementara 2 kapal lainnya, yaitu KM Dewi Putri dan KM Berkat belum mengimplementasikan ketentuan tersebut. 


\section{Pembahasan}

Asuransi kerangka kapal di Indonesia mulai diwajibkan pada tahun 2015 oleh Direktorat Jenderal Pehubungan Laut (DJPL) melalui surat edaran wajib asuransi kapal kepada pemilik kapal. Surat edaran kewajiban asuransi kapal Nomor AL.801/1/2 Phb 2014 dibuat untuk melengkapi ketentuan hukum, diantaranya yaitu UU No. 17/2008 tentang Pelayaran, PP No. 5/2010, dan PermenHub No.71/2013. Dalam UU No.17/2008 (Pasal 203), pemerintah meminta kepada pemilik kapal untuk menyingkirkan kerangka kapal dan muatannya maksimal 180 hari kerja sejak kapal tenggelam. Pemilik kapal wajib mengasuransikan kapalnya untuk menjamin tanggung jawab pemilik kapal menyingkirkan kerangka kapalnya seperti yang disebutkan. Selanjutnya, PP No. 5/2010 (Pasal 119) menyebutkan bahwa kewajiban asuransi kapal, dikecualikan bagi kapal perang, kapal negara yang digunakan untuk tugas pemerintahan, kapal layar, dan kapal motor dengan ukuran kurang dari 35 GT. Selanjutnya, PermenHub No.71/2013 Pasal 18 menyebutkan bahwa pemilik kapal wajib mengasuransikan kapalnya dengan asuransi atas kewajiban menyingkirkan kerangka kapal (wreck removal insurance) dan/atau asuransi perlindungan dan ganti rugi (protection and indemnity) dibuktikan dengan polis asuransi atau sertifikat dana jaminan penyingkiran kerangka kapal, yang wajib dilampirkan sebagai persyaratan kelaikan kapal dan pengoperasian kapal di pelabuhan. Berdasarkan surat edaran tersebut, Perum Perindo baru melaksanakan asuransi kapal pada tahun 2019, dikarenakan perlunya waktu untuk penyusunan dana pendapatan guna membayar premi asuransi.

Adanya surat edaran dapat memperkuat ketentuan hukum kewajiban asuransi kapal. Di dalam surat juga dilengkapi tata cara pengenaan sanksi dan tata cara kewajiban dari pemilik kapal untuk melaporkan kerangka kapal yang tenggelam. Apabila pemilik kapal tidak mematuhi ketentuan tersebut, maka akan dikenakan sanksi administratif berupa peringatan, pembekuan izin, hingga pencabutan izin. Jika kapal tidak diasuransikan dan mengalami kecelakaan di laut yang menyebabkan pencemaran dan rusaknya ekosistem laut sehingga mengganggu jalur pelayaran maka dikenakan sanksi perdata bahkan sanksi pidana. Hal ini selaras dengan pernyataan Nagara (2017) bahwa setiap orang atau instansi yang menyebabkan pencemaran di wilayah laut yang berada di dalam kedaulatan Indonesia dapat dikenakan sanksi perdata yang mencakup ganti kerugian, tanggung jawab mutlak, dan pembebasan tanggung jawab. Terkait adanya surat edaran tersebut, DJPL mengadakan sosialisasi kepada stakeholder terkait dengan mengadakan seminar tentang pelaksanaan kewajiban asuransi kerangka kapal (wreck removal insurance) pada tanggal 24 Februari 2015. Saat ini, DJPL juga mempersiapkan ratifikasi Konvensi Internasional Nairobi untuk keselamatan dan keamanan pelayaran kapal serta perlindungan terhadap lingkungan laut (www.dephub.go.id).

Hasil penelitian yang dilakukan di Perum Perindo sebagai salah satu pemilik kapal yang menerima surat edaran tersebut, saat ini Perum Perindo memiliki lima kapal perikanan, yaitu KM Perindo Jaya, KM Setia Utama, KM Gemilang Samudera, KM Dewi Putri, dan KM Berkat. Tiga kapal sudah diasuransikan, yaitu KM Perindo Jaya, KM Setia Utama, dan KM Gemilang Samudera karena sudah memenuhi persyaratan kelengkapan dokumen kepemilikan kapal untuk asuransi, yaitu grosse akta, surat ukur, dan pas besar. Sementara itu dua kapal lainnya, yaitu KM Dewi Putri dan KM Berkat belum dapat diasuransikan karena belum memiliki surat ukur dan pas besar sehingga kapal tersebut tidak dapat beroperasi atau berlayar. Surat ukur dan pas besar tersebut belum diperoleh, karena kedua kapal baru dibeli oleh Perum Perindo sehingga saat ini masih dalam proses peralihan kepemilikan.

Persyaratan dokumen kepemilikan kapal untuk pengajuan asuransi harus dipenuhi untuk keamanan pelayaran dan perlindungan kerugian kepada pemilik kapal. Persyaratan dari dua kapal milik Perum Perindo yang belum terpenuhi adalah surat ukur dan pas besar. Penerbitan surat ukur dan pas besar dilakukan oleh Syahbandar di pelabuhan tempat kapal berada. Hal ini ditegaskan dalam PermenHub No. 8/2013 dan PermenHub No. 39/2017. Surat ukur diperoleh dengan cara melakukan pengukuran pada kapal oleh ahli ukur yang diberi kewenangan untuk melaksanakan pengukuran kapal. Pas besar sebagai tanda pendaftaran dan kebangsaan kapal diperoleh dengan cara mendaftarkan kapal yang dimiliki ke kantor pusat DJPL atau syahbandar setempat, wajib dilengkapi dengan bukti hak milik 
atas kapal, identitas pemilik kapal, nomor pokok wajib pajak, surat ukur, laporan pemeriksaan keselamatan kapal yang dibuat oleh pejabat pemeriksa keselamatan kapal, surat kuasa untuk mengajukan permohonan dan pengurusan pendaftaran kapal dari pemilik kapal (apabila dikuasakan), bukti pelunasan bea balik nama kapal sesuai dengan ketentuan peraturan perundangundangan, dan rekomendasi dari menteri yang bertanggung jawab terhadap kegiatan khusus kapal penangkap ikan.

Pentingnya asuransi kerangka kapal membutuhkan rekomendasi pelaksanaanya, rekomendasi yang pertama yaitu pemilik kapal wajib melengkapi persyaratan dokumen kepemilikan kapal sebagai bukti kepemilikan yang sah. Kapal yang berlayar di perairan Indonesia wajib memiliki asuransi penyingkiran kerangka kapal dan perlindungan ganti rugi sebagaimana diatur dalam Konvensi Internasional Nairobi. Konvensi tersebut menetapkan kewajiban ketat pada pemilik kapal untuk mencari, menandai, dan mengangkat bangkai kapal yang dianggap bahaya dan mewajibkan pemilik kapal untuk membuat sertifikasi asuransi negara atau bentuk asuransi lain untuk keamanan keuangan pemilik kapal (www.dephub.go.id). Pemilik kapal perikanan dapat memanfaatkan aset kapal kayu untuk pengajuan asuransi yang sesuai dengan aturan Biro Klasifikasi Indonesia (BKI), kapal tersebut harus dilengkapi dengan syarat-syarat umum yang ditentukan menggunakan gambargambar desain seperti general arrangement, lines plan, midship section, dan construction profile (Rachman et al. 2012). Rekomendasi selanjutnya, yaitu pemilik kapal harus menyusun dana pendapatan guna membayar premi asuransi secara berkala kepada pihak ketiga yaitu perusahaan asuransi. seseorang atau badan usaha ingin memiliki asuransi haruslah membayar premi yang sesuai dengan kebutuhan dan jumlah pertanggungan yang disusun secara rinci sehingga tidak mengakibatkan mogoknya pembayaran premi kepada pihak penanggung sebagai pengganti kerusakan, kerugian, maupun kehilangan (Agustiranda et al. 2019).

\section{KESIMPULAN DAN SARAN}

\section{Kesimpulan}

Perum Perindo hanya tiga kapal dari lima kapal yang beroperasi yang memiliki asuransi kerangka kapal. Hal ini disebabkan dua kapal lainnya belum memiliki surat ukur dan pas besar untuk pemenuhan persyaratan asuransi. Berdasarkan aturan mengenai asuransi kerangka kapal, yaitu UU No.17/2008, PP No.5/2010, dan PerMenHub No.71/2013, Perum Perindo wajib mengasuransikan seluruh kapal yang beroperasi agar terhindar dari tuntutan perdata dan pidana. Pemenuhan asuransi kapal ini menjadi pembelajaran bagi pemilik kapal lain, baik perseorangan maupun korporasi dalam menjalankan kegiatan penangkapan ikan yang menggunakan kapal ikan di atas 35 GT.

\section{Saran}

Asuransi kerangka kapal perlu dimiliki bagi setiap pemilik kapal untuk menjaga aset sebagai modal usaha agar terhindar dari risiko kerugian akibat peristiwa yang tidak pasti dan pemilik kapal terhindar dari sanksi yang diberikan oleh Direktorat Jenderal Perhubungan Laut.

\section{DAFTAR PUSTAKA}

Agustiranda W, Yuliani, Samadi WB. 2019. Pengaruh Pendapatan Premi, Pembayaran Klaim, dan Risk Based Capital terhadap Pertumbuhan Laba Perusahaan. Jurnal Ilmiah Manajemen Bisnis dan Terapan. 14(1): 1-12.

Badriyah S, Mahmudah S, Soemarni A. 2019. Leasing sebagai Alternatif Pembiayaan. Jurnal MasalahMasalah Hukum. 2(2): 204-214.

[BKI] Biro Klasifikasi Indonesia. 1996. Buku Peraturan Klasifikasi dan Konstruksi Kapal Kayu. Jakarta (ID): Klasindo Jakarta.

[BKI] Biro Klasifikasi Indonesia. 2014. Menjadi Badan Klasifikasi Profesional Terkemuka dalam Rangka Membangun Industri Maritim Asia. Laporan Tahunan Annual Report BKI 2014. Jakarta (ID): PT Biro Klasifikasi Indonesia.

Budiarto U, Jokosisworo S. 2012. Pembuatan Perangkat Lunak Konstruksi Kapal Perikanan berdasarkan Peraturan Klasifikasi dan Konstruksi Kapal Kayu BKI 1996. Jurnal Kapal. 9(3): 130-137.

Budiman MS, Iskandar $\mathrm{BH}$, Seboer DA. 2016. Penataan Sertifikasi Kompetensi Awak Kapal Penangkap 
Ikan di Indonesia (Arrangement of Certification Competence Crew of Fishing Vessel in Indonesia). 7(2): 145-152.

[DJPL] Direktorat Jenderal Perhubungan Laut. 2015. Wajib Asuransi Kapal diatas 35 GT untuk Lindungi Pemilik Kapal. www.dephub.go.id. [19 November 2019].

Ginting B. 2013. Perkembangan Hukum Perdata di Indonesia. Jurnal Hukum. 9(20): 1-9.

Ilyas A. 2012. Asas-Asas Hukum Pidana Memahami Tindak Pidana dan Pertanggungjawaban Pidana sebagai Syarat Pemidanaan. Makassar (ID): Rangkang Education Yogyakarta \& PuKAP-Indonesia.

[KemenHub] Kementerian Perhubungan Republik Indonesia. 2013. Peraturan Menteri Perhubungan No. 8 Tahun 2013 tentang Pengukuran Kapal.

[KemenHub] Kementerian Perhubungan Republik Indonesia. 2013. Peraturan Menteri Perhubungan No. 71 Tahun 2013 tentang Salvage dan/atau Pekerjaan Bawah Air.

[KemenHub] Kementerian Perhubungan Republik Indonesia. 2017. Peraturan Menteri Perhubungan RI No. 39 Tahun 2017 tentang Pendaftaran dan Kebangsaan Kapal.

[Kemenhukham] Kementerian Hukum dan HAM Republik Indonesia. 1938. Kitab Undang-Undang Hukum Dagang.

Lindawati, Rahadian R. 2016. Identifikasi Faktor dan Penilaian Risiko pada Usaha Perikanan Tangkap di Kabupaten Sambas. Jurnal Sosial Ekonomi Perikanan Kelautan. 11(1): 99-10.

Mardiyah A. 2013. Analisis Prosedur Penanganan Klaim Asuransi Kecelakaan Diri pada PT. Asuransi Umu Bumiputeramuda 1967. Jurnal Pendidikan Ilmu Pengetahuan Sosial. 106.

Maulida JF. 2014. Deskripsi Rantai Pasok Ikan Tuna (Studi Kasus PT. AWIndo Internasional di Pelabuhan Perikanan Samudera Nizam Zachman Jakarta) [Skripsi]. Bogor (ID): Institut Pertanian Bogor.

Muchsam Y, Falahah, Saputro GI. 2011. Penerapan Gap Analysis pada Pengembangan Sistem Pendukung Keputusan Penilaian Kinerja
Karyawan (Studi Kasus PT. XYZ). Seminar Nasional Aplikasi Teknologi Informasi 2011. 17-18 Juni 2011.

Muchtar H. 2015. Analisis Yuridis Normatif Sinkronisasi Peraturan Daerah dengan Hak Asasi Manusia. Jurnal Humanus. 14(1): 1-12.

Nagara G. 2017. Perkembangan Sanksi Administratif dalam Perlindungan Lingkungan Terkait Eksploitasi Sumber Daya Alam. Jurnal Hukum Lingkungan Indonesia. 3(2): 19-44.

Njatrijani R. 2018. Klaim Marine Hull and Machinery dalam Praktek Pertanggungan. Jurnal Diponegoro Law Review. 3(1): 326-344.

Nasir M. 2016. Perasuransian. Jakarta (ID): Kementerian Riset, Teknologi, dan Pendidikan Tinggi.

Novi MN, Njatrijani R, Aminah. 2016. Tanggung Jawab Penanggung terhadap Klaim Tertanggung dalam Pelaksanaan Asuransi Marine Hull and Machinery. Jurnal Diponegoro Law Review. 5(16) : 1-5.

Nugroho A. 2011. Seluk Beluk Perusahaan Asuransi. Sleman (ID): PT Intan Sejati Klaten.

Parappurathu S, Ramachandran C, Gopalakrishnan A, dkk. 2017. Marine Fisheries Information Service. Technical and Extension Series. India (IND): Indian. Council of Agricultural Research.

[PP] Peraturan Pemerintah Republik Indonesia Nomor 51 Tahun 2002 tentang Perkapalan.

[PP] Peraturan Pemerintah Republik Indonesia Nomor 5 Tahun 2010 tentang Kenavigasian.

Rachman A, Misbah MN, Wartono M. 2012. Kesesuaian Ukuran Konstruksi Kapal Kayu Nelayan di Pelabuhan Nelayan (PN) Gresik Menggunakan Aturan Biro Klasifikasi Indonesia (BKI). Jurnal Teknik ITS. 1(1): 84-87.

Rani M. 2016. Insurance Protection for Fisherman. Jurnal Selat. 4(1): 5-9.

Sugiyono. 2010. Memahami Penelitian Kualitatif. Bandung (ID): Alfabeta.

Tjahjanto R, Aziz I. 2016. Analisis Penyebab Terjadinya Kecelakaan Kerja di Atas Kapal MV. CS Brave. Jurnal Kapal. 13(01): 13-18.

Undang-Undang Republik Indonesia Nomor 17 Tahun 2008 tentang Pelayaran. Jakarta (ID): Sekretariat Negara.

Undang-Undang Republik Indonesia Nomor 
19 Tahun 2013 tentang Badan Usaha Milik Negara. Jakarta (ID):

Sekretariat Negara.

Undang-Undang Republik Indonesia Nomor 40 Tahun 2014 tentang Perasuransian. Jakarta (ID): Sekretariat Negara.

Utomo H. 2017. Legality Responsible Parties in Ship Accident. Jurnal Legalisasi Indonesia. 14(01): 57-76.

Zaini ZD. 2011. Implementasi Pendekatan Yuridis Normatif dan Pendekatam Normatif. Jurnal Pranata Hukum. 6(2): 1-16. 